\title{
Kepercayaan Konsumen Memediasi Omnichannel Integration Quality Pada Niat Pembelian Kembali di PT Pegadaian (Persero) Medan
}

\author{
Britto E Simatupang, Romindo M Pasaribu*, Agus N Simanjuntak, Herry D.S Pasaribu, Vinsensius Matondang \\ Program Studi Manajemen Pemasaran, Fakultas Ekonomi dan Bisnis, Universitas HKBP Nommensen, Medan, Indonesia \\ Email: ${ }^{1}$ estersimatupang1103@gmail.com, ${ }^{2,}{ }^{*}$ megawati.pasaribu@gmail.com, ${ }^{3}$ agus.nakkok.simanjuntak@gmail.com, \\ ${ }^{4}$ herry.pasaribu@gmail.com \\ Email Penulis Korespondensi: megawati.pasaribu@gmail.com \\ Submitted: 10/11/2021; Accepted: 26/11/2021; Published: 30/11/2021
}

\begin{abstract}
Perusahaan yang mampu memberikan layanan secara terintegrasi akan meningkatkan interaksi dengan perusahaan dengan tujuan menciptakan pengalaman yang konsisten mengenai pengalaman produk kepada konsumen. Hal ini disebut sebagai metode saluran omnichannel marketing yang mengintegrasikan layanan digital (penggunaan aplikasi) dengan physical (in-store) kepada konsumen untuk memiliki pengalaman dan kemudahan dalam bertransaksi dengan perusahaan. Penelitian ini bertujuan untuk memberikan bukti empiris mengenai konfigurasi saluran layanan dan interaksi terintegrasi terhadap niat pembelian kembali produk jasa PT Pegadaian Cabang Madya Medan. Lebih lanjut, variabel kepercayaan digunakan sebagai variabel mediating untuk meningkatkan keinginan konsumen melakukan pembelian kembali. Dengan menggunakan teknik purposive sampling digunakan kriteria dalam pengambilan sampel penelitian; diperoleh sebanyak 103 valid respon melalui pengumpulan data secara acak kepada responden dengan menggunakan google formulir. Analisis Struktural Equation Modeling (SEM) digunakan untuk menguji model pengukuran dan structural melalui Smart-PLS 3.0. Hasil penelitian ini menunjukkan bahwa (1) variabel konfigurasi saluran layanan dan saluran terintegrasi berpengaruh signifikan terhadap kepercayaan; (2) konfigurasi saluran layanan berpengaruh signifikan terhadap minat pembelian kembali, (3) akan tetapi variabel interaksi terintegrasi berpengaruh tidak signifikan terhadap niat pembelian kembali. Sementara itu, (4) variabel kepercayaan secara signifikan memediasi variabel konfigurasi saluran layanan dan interksi terintegrasi terhadap niat pembelian kembali. Kontribusi empiris dan teoritis didiskusikan pada pembahasan penelitian ini.
\end{abstract}

Kata Kunci: Omnichannel Marketing; Konfigurasi Saluran Layanan; Interaksi Terintegrasi; Kepercayaan; Niat Pembelian Kembali; Pegadaian

\begin{abstract}
Companies that are able to provide integrated services will increase interactions with companies with the aim of creating a consistent product experience for consumers. This is referred to as the channel method omnichannel marketing which integrates digital services (application usage) with physical (in-store) to consumers to have experience and convenience in transacting with the company. This study aims to provide empirical evidence regarding the configuration of service channels and integrated interactions on the repurchase intention of PT Pegadaian Branch Madya Medan's service products. Furthermore, the trust variable is used as a mediating variable to increase consumers' desire to repurchase. By using the technique purposive sampling used criteria in taking research samples; obtained as many as 103 valid responses through random data collection to respondents using google forms. Analysis Structural Equation Modeling (SEM) used to test the measurement and structural models through Smart-PLS 3.0. The results of this study indicate that (1) the variable configuration of the service channel and integrated channel has a signific ant effect on trust; (2) service channel configuration has a significant effect on repurchase intention, (3) but the integrated interaction variable has no significant effect on repurchase intention. Meanwhile, (4) the trust variable significantly mediates the service channel configuration variable and the integrated interaction on repurchase intention. Empirical and theoretical contributions are discussed in the discussion of this research.
\end{abstract}

Keywords: Omnichannel Marketing; Service Channel Configuration; Interaction Integrated; Trust; Purchase Intention; Pegadaian

\section{PENDAHULUAN}

Pegadaian digital service merupakan layanan digital Pegadaian dalam bentuk aplikasi berbasis web dan/atau mobile yang dapat memberikan pelayanan produk Pegadaian untuk membantu nasabah melakukan pembelian investasi, transaksi. Gadai dan beragam produk- produk pegadaian lainnya melalui smartphone. Dimana Aplikasi Pegadaian bisa diunduh di Playstore bagi pengguna Android dan Appstore bagi pengguna iOS.

Omnichannel merupakan model bisnis yang dalam pengoperasian dan pelayanannya terintegrasi pada semua saluran penjualan yang dimiliki perusahaan dalam saru sistem secara keseluruhan. Omnichannel menggabungkan semua saluran pemasaran toko baik secara online maupun offline yang saling terintegrasi dengan tujuan dapat mempermudah pelanggan untuk mencari informasi, mengolah, dan mengambil keputusan dalam melakukan pembelian produk. Strategi pemasaran omni-channel dalam produk tabungan emas guna menyesuaikan dengan kondisi konsumen era indistri 4.0 saat ini. Kannanb, dan Inman dalam Yan, Kwak (2016:39) mendefenisikan saluran omni sebagai manajemen strategi dari berbagai saluran yang tersedia dan titik kontak pelanggan, sedemikian rupa sehingga pengalaman pelanggan di seluruh saluran dan kinerja melalui saluran dioptimalkan.

Munculnya minat konsumen akan mendorong konsumen untuk mengetahui lebih dalam mengenai kualitas toko online. Hal ini akan membangun kepercayaan atas informasi yang diperoleh. Kepercayaan konsumen memiliki pengaruh yang besar terhadap keberlangsungan produk perusahaan yang ditawarkan. Bila produk yang ditawarkan tidak mendapatkan kepercayaan konsumen maka produk tersebut akan sulit berkembang, dan sebaliknya produk yang mendapat kepercayaan konsumen akan menarik minat beli konsumen. Untuk dapat menarik minat beli konsumen baru dapat dilakukan dengan memberikan informasi yang lengkap dan detail kepada calon konsumen melalui omni-channel integritas quality. Mowen dan Minor (2013:201), kepercayaan konsumen ialah semua pengetahuan yang dimiliki oleh 
konsumen dan semua kesimpulan yang dibuat oleh konsumen tentang objek, atribut dan manfaatnya. Kepercayaan ini yang harus didapatkan oleh perusahaan, semakin konsumen percaya, perusahaan akan terus menjalani hubungan yang baik dengan konsumen dan menarik konsumen semakin berminat.

Tujuan dari penelitian adalah 1) Untuk mengetahui pengaruh omnichannel integrated quality (konfigurasi saluran layanan dan interaksi terintegrasi) terhadap kepercayaan niat pembelian kembali, 3) Untuk mengetahui pengaruh omnichannel integrated quality (konfigurasis layanan dan konfigurasi saluran layanan dan interaksi terintegrasi) terhadap niat pembelian kembali, 4) Untuk mengetahui pengaruh omnichannel integrated quality (konfigurasi saluran layanan dan interaksi terintegrasi) terhadap niat pembelian kembali dengan kepercayaan pelanggan sebagai variabel mediasi.

\section{METODE PENELITIAN}

\subsection{Kerangka Dasar Penelitian}

Penelitian ini adalah deskriptif kuantitatif. Sinulingga (2013), penelitian deskriptif kuantitatif merupakan suatu jenis penelitian yang bertujuan untuk mendeskripsikan secara sistematik, faktual, dan akurat mengenai fakta dan sifat suatu objek atau populasi tertentu. Adapun variabel yang dihubungkan yaitu: variabel independen, konfigurasi saluran layanan (X1) dan interaksi terintegrasi (X2) dengan variabel dependen niat pembelian kembali (Y) serta menggunakan variabel mediasi kepercayaan (Z). Lokasi penelitian ini dilakukan di PT Pegadaian (Persero) Medan Sumatera Utara. Waktu Penelitian dilaksanakan pada bulan Mei 2021 sampai dengan selesai. Teknik pengambilan sampel menggunakan metode nonprobability sampling dengan metode purposive sampling. Dengan kriteria yang ditentukan peneliti untuk menjadi sampel yaitu masyarakat Kota Medan berusia 18-38 tahun yang pernah melakukan pembelian di Pegadaian digital service dan minimal 6 bulan dalam penggunaan aplikasi Pegadaian digital service. Jumlah sampel dalam penelitian ini sebanyak 103 responden. Teknik analisis data dilakukan dengan metode Partial Least Square (PLS) menggunakan software SmartPLS versi 3.

\subsection{Kerangka Penelitian dan Pengembangan Hipotesis}

\section{a. Hubungan Omnichannel Integration Quality terhadap Kepercayaan Konsumen}

Omni-channel integration quality adalah kondisi dimana ketika terdapat integrasi channel yang mampu menyediakan layanan tanpa batas bagi pelanggan di berbagai saluran. Seck dan Philippe (2013), menyatakan omnichannel integration quality mengacu pada koordinasi antara berbagai bentuk interaksi yang digunakan oleh suatu perusahaan seperti situs web, toko fisik dan saluran lainnya. Sousa \& Voss (2006), kualitas saluran integrasi mengacu pada kemampuan perusahaan untuk menyediakan pengalaman membeli pelanggan yang mulus (seamless) diseluruh saluran. Hal ini merupakan kunci untuk mengelola hubungan pelanggan diseluruh saluran (Payne \& Frow, 2004), dan menjadi bagian terpenting dari omnichannel ritel. Dengan kata lain, untuk memanfaatkan omnichannel semaksimal mungkin, perusahaan (pengecer) perlu melakukan dan memastikan saluran integrasi yang sinergis yang menghilangkan adanya gesekan selama perjalanan pelanggan, guna menimbulkan tingkat kepercayaan konsumen (Bianchi dkk., 2016; BusinessWire, 2016). Dalam hal ini peneliti menduga bahwa terdapat hubungan omnichannel integration quality terhadap kepercayaan konsumen. Maka dirumuskan hipotesis sebagai berikut:

Hla: Terdapat pengaruh yang positif dan signifikan antara konfigurasi saluran layanan terhadap kepercayaan konsumen

HIb: Terdapat pengaruh yang positif dan signifikan antara interaksi terintegrasi terhadap kepercayaan konsumen

\section{b. Hubungan Kepercayaan terhadap Niat Pembelian Kembali}

Kepercayaan merupakan salah satu pondasi dari bisnis apapun, suatu transaksi bisnis antara dua belah pihak atau lebih akan terjadi apabila masing-masing pihak saling mempercayai. Kepercayaan ini tidak begitu saja dapat diakui oleh pihak lain/mitra bisnis, melainkan harus dibangun mulai dari awal dan dapat dibuktikan. Nohemaya (2016:85) kepercayaan konsumen berpengaruh positif dan signifikan terhadap minat beli ulang secara online. Pengaruh ini sangat menguntungkan bagi reseller atau pelaku jualan online terbukti dengan banyaknya minat konsumen untuk melakukan pembelian secara online. Artinya, semakin tinggi kepercayaan yang diberikan konsumen maka semakin tinggi pula minat yang timbul pada diri konsumen untuk melakukan pembelian secara online. Dengan demikian peneliti menduga terdapat hubungan kepercayaan terhadap niat pembelian kembali. Maka dirumuskan hipotesis sebagai berikut:

H2: Terdapat pengaruh yang positif dan signifikan antara kepercayaan terhadap niat pembelian kembali

\section{c. Hubungan Omnichannel Integration Quality terhadap Niat Pembelian Kembali}

Kehadiran omnichannel ditengah masyarakat semakin mempermudah konsumen untuk melakukan kegiatan transaksi maupun membeli produk yang diinginkan. Kemajuan teknologi telah mempermudah konsumen, dimana konsumen tidak perlu mendatangi toko atau retail untuk membeli produk. Tujuan omnichannel adalah untuk mempermudah, mempersingkat waktu dan menimbulkan rasa niat keingintauan serta minat beli masyarakat terhadap produk yang ditawarkan. Sehingga dengan adanya perkembangan konfigurasi saluran layanan yang ditawarkan melalui digital service akan berpengaruh terhadap niat pembelian kembali konsumen.

Interaksi terintegrasi pada omnichannel marketing berpengaruh terhadap niat pembelian kembali konsumen, dimana konsumen akan terkoneksi dengan lebih mudah dengan adanya digital marketing, dengan seluruh saluran yang 
saling terintegrasi satu sama lain. Sugesti, Kusniawati dan Prabowo (2019), tentang pengaruh omnichannel marketing terhadap minat beli konsumen (suatu studi pada produk tabungan emas PT Pegadaian (Persero) Syariah), menunjukkan bahwa omnichannel marketing berpengaruh positif dan signifikan terhadap minat beli. Dengan demikian peneliti niat pembelian kembali niat pembelian kembali. Maka dirumuskan hipotesis sebagai berikut:

H3a: Terdapat pengaruh yang positif dan signifikan antara konfigurasi saluran terhadap niat pembelian kembali

$\mathrm{H} 3 \mathrm{~b}$ : Terdapat pengaruh yang positif dan signifikan antara interaksi terintegrasi terhadap niat pembelian kembali

\section{d. Hubungan Omnichannel Integration Quality terhadap Niat Pembelian kKembali Melalui Kepercayaan sebagai Variabel Mediasi.}

Strategi integrasi multisaluran melibatkan keputusan mengenai jumlah saluran yang akan diadopsi, hal ini bersifat interaksi antara perusahan (pengecer) dan saluran apa yang ditawarkan kepada pelanggan dan untuk tujuan apa (Neslin dan Grewal, 2006), jaminan bahwa pelanggan mengalami interaksi yang positif dan konsisten dengan mereka semua (Payne dan Frow, 2004). Studi sebelumnya memberikan beberapa klasifikasi konstruksi integrasi multisaluran pengecer. Saeed dkk, (2003) mengemukakan bahwa integrasi sistem informasi pendukung saluran virtual dan fisik dapat disajikan dalam bentuk layanan nilai tambah yang dikategorikan sebagai konten, informasi integrasi dan logistik. Berman dan Thelen (2004), mengusulkan bahwa karakteristik umum dari strategi ritel yang terintegrasi dengan baik meliputi: tingginya integrasi promosi, konsistensi produk lintas saluran, sistem informasi yang terintegrasi untuk membagikan data pelanggan, harga, dan inventaris ke beberapa saliran, proses yang memungkinkan untuk melakukan pengambilan ditoko untuk produk yang dibeli melalui web, dan mencari peluang multisaluran dengan mitra yang sesuai.

Hal ini dianggap sebagai kunci untuk mengelola hubungan pelanggan diseluruh saluran (Payne dan Frow, 2004), dan terletak pada omnichannel ritel. Dengan kata lain, untuk memanfaatkan omnichannel semaksimal mungkin, perusahaan akan lebih mudah mendapatkan kepercayaan dari konsumen terhadap produk perusahaan yang ditawarkan, sehingga ini juga akan mempengaruhi niat pembelian kembali konsumen. Demikian peneliti menduga terdapat pengaruh omni-channel integration quality terhadap niat pembelian kembali melalui kepercayaan sebagai mediasi. Maka dirumuskan hipotesis sebagai berikut:

H4a: Terdapat pengaruh yang positif dan signifikan antara konfigurasi saluran layanan terhadap niat pembelian kembali

H4b: Terdapat pengaruh yang positif dan signifikan antara interaksi terintegrasi terhadap niat pembelian kembali

Dari kerangka berpikir diatas dapat dibuat paradigma penelitian untuk menggambarkan kerangka pemikiran ini. Berikut gambar rangka pemikiran peneliti:

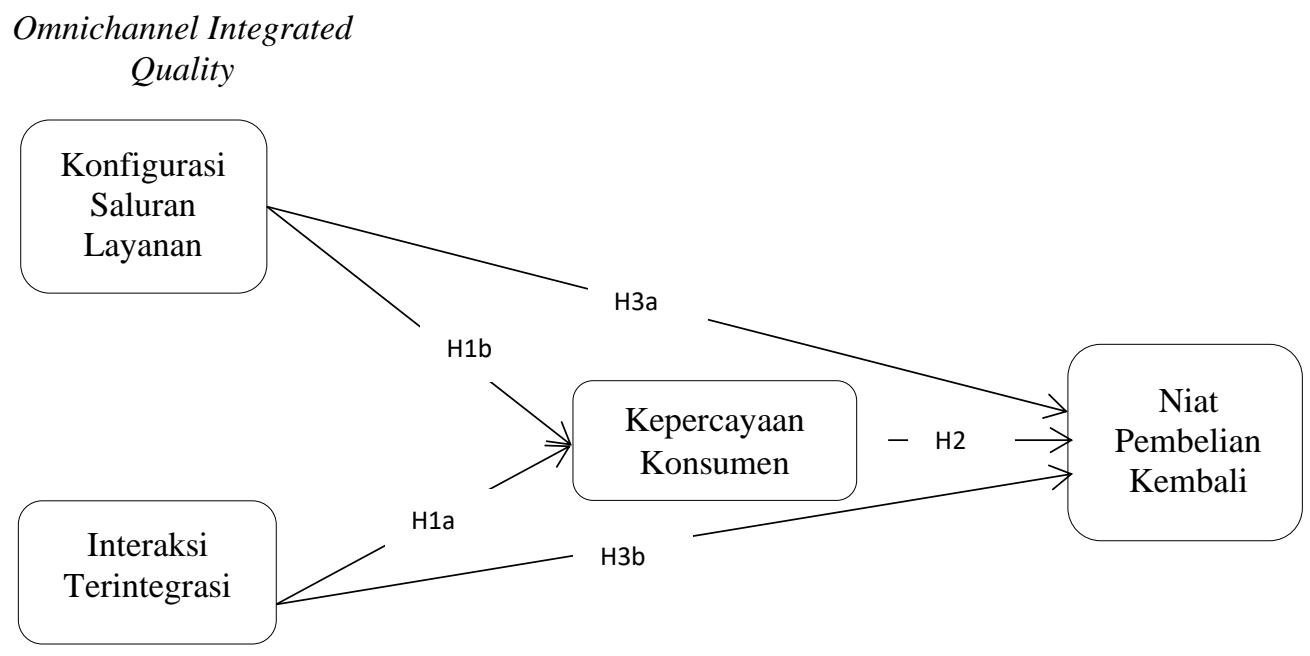

Gambar 1. Kerangka Penelitian

\subsection{Niat Pembelian Kembali}

Niat adalah kecenderungan seseorang untuk merasa tertarik pada objek tertentu yang dianggap paling penting. Niat membeli dapat diartikan sebagai keinginan untuk membeli yang merupakan dari bagian proses menujuh kearah tindakan pembelian yang dilakukan oleh seorang konsumen. Kotler dan Keller (dalam Adi, 2015:36), menyatakan niat pembelian konsumen merupakan sebuah perilaku konsumen dimana konsumen mempunyai keinginan dalam memilih, menggunakan, dan mengkonsumsi atau bahkan menginginkan suatu produk yang ditawarkan. Tjiptono (2015:140), minat beli adalah konsumen mencerminkan hasrat dan keinginan untuk membeli suatu produk, sehingga menimbulakan keinginan untuk membeli kembali produk yang sudah pernah dibeli. Hasan (2018:131) bahwa niat pembelian kembali merupakan minat pembelian berdasarkan atas pengalaman pembelian yang telah dilakukan dimasa lalu. Niat pembelian kembali yang tinggi mencerminkan tingkat kepuasan yang tinggi dari konsumen. Hasan (2018:131), mengidentifikasi indikator dari niat pembelian kembali sebagai berikut:

1. Minat transaksional, yaitu kecenderungan seseorang untuk membeli produk. 
2. Minat referensi, yaitu kecenderungan seseorang untuk mereferensikan kepada orang lain

3. Minat preferensial, yaitu minat yang menggambarkan perilaku seseorang yang memiliki prefensial utama pada produk, preferensi ini hanya dapat diganti bila terjadi sesuatu dengan produk preferensinya.

4. Minat exploratif, minat ini menggambarkan perilaku seseorang yang selalu mencari informasi mengenai produk yang diinginkannya dan mencari informasi untuk mendukung sifat-sifat positif dari produk yang sama.

\subsection{Omnichannel Integrated Quality}

Omnichannel berasal dari kata Omnis yang artinya semua atau universal. Omnichannel menggabungkan saluran komunikasi yang paling relevan bersama didalam satu antar muka untuk membuat garis waktu yang komprehensif dari interaksi perusahaan dengan pelanggan. Omnichannel merupakan strategi konten lintas saluran yang digunakan perusahaan untuk meningkatkan pengalaman pengguna pelanggannya. Omnichannel mengharuskan adanya intergrasi satu sama lain dan pengaturan saluran baik secara online maupun offline yang saling terinterasi sehingga melibatkan pengalaman disemua saluran yang dipilih seseorang untuk digunakan, atau bahkan lebih efisien dan menyenangkan daripada menggunakan saluran tunggal secara terpisah. Pemasaran omni-channel menggambarkan strategi yang konsisten dan terkoordinasi khususnya untuk berinteraksi dengan pelanggan dan calon pelanggan, dan bagaimana memberikan pelayanan yang terbaik kepada pelanggan menggunakan saluran yang tepat bagi mereka, pada saat yang tepat dalam situasi yang tepat pula. Sousa dan Voss (2006), Omnichannel integration quality terbagi menjadi 2 kategori, yaitu konfigurasi saluran layanan dan interaksi terintegrasi. Pada dimensi konfigurasi saluran layanan memiliki 2 indikator, yaitu luasnya pilihan saluran layanan dan transparansi konfigurasi saluran layanan. Dan pada dimensi interaksi terintegrasi memiliki 2 indikator, yaitu konsistensi konten dan konsistensi proses.

\subsection{Konfigurasi Saluran Layanan}

Konfigurasi saluran layanan mengacu pada kombinasi yang tersedia dari komponen layanan dan saluran pengiriman yang terkait (Sousa \& Voss, 2006), yang diwujudkan melalui luasnya sub dimensi, yaitu pilihan saluran layanan dan transparansi konfigurasi saluran layanan. Saluran layanan mengacu pada sejauh mana pelanggan dapat memilih saluran alternatif untuk layanan tertentu atau dapat menyelesaikan tugas yang disukai melalui saluran individu. Pengecer dapat menunjukkan keunggulan dalam konfigurasi layanan saluran dengan memungkinkan pelanggan untuk memesan secara online dan offline. Transparansi konfigurasi saluran layanan mengacu pada sejauhmana pelanggan mengetahui keberadan saluran dan layanan yang tersedia serta perbedaan antara atribut layanan tersebut dalam lintas saluran. Ketika pengecer tidak dapat mengintegrasikan saluran mereka dengan benar, pelanggan akan mengalami kebingungan dengan ketersediaan dan perbedaan layanan lintas saluran, kebingungan seperti ini dapat membebani kesulitan dalam perjalanan pembelian pelanggan (Bitner et al., 2002).

\subsection{Interaksi terintegrasi}

Interaksi integrasi mengacu pada konsistensi interaksi lintas saluran (Sousa \& Voss, 2006), yang diwujudkan melalui sub dimensi, yaitu konsistensi konten dan konsistensi proses. Konsistensi konten, mengacu pada konsistensi konten yang disediakan oleh pengecer diseluruh saluran (Sousa \& Voss, 2006). Konsisten konten memungkinkan pelanggan menerima tanggapan berupa pertanyaan yang diposting disaluran online atau fisik. Perusahaan harus menyediakan konten yang konsisten (misalnya konten, harga, spesifikasi produk, dan layanan jaminan) diseluruh saluran pengecer yang mampu memberikan nilai pertukaran yang bernilai kepada pelanggan. Konsisten konten sangat penting dalam membentuk pengalaman berbelanja yang mulus (Cox, 2016). Tanpa konten yang konsisten yang tersedia diseluruh saluran, pelanggan akan mudah frustasi saat mereka pindah dari saluran ke saluran (Matt, 2016). Dengan kata lain, konsistensi konten dapat membantu menghilangkan hambatan dalam perjalanan belanja pelanggan dan mempersingkat proses transaksi, perusahaan akan menghargainya dan menjadi lebih terlibat (Lexmark, 2016). Konsisten proses, mengacu pada tingkat konsistensi dari proses yang relevan dan dapat membandingkan atribut diseluruh saluran, seperti rasa, citra, dan kecepatan pengiriman layanan (Sousa \& Voss, 2006). Studi mengenai riset pasar menunjukkan 59\% responden melaporkan ketidakkonsistenan dalam pengalaman berbelanja yang berpindah dari satu saluran ke saluran yang lain dapat membuat pelanggan merasa kesal (Gilles, 2015).

\subsection{Kepercayaan}

Kepercayaan merupakan keyakinan dimana seseorang akan mendapatkan apa yang diharapkan dari orang lain. Kepercayaan menyangkut kesediaan seseorang agar berprilaku tertentu karena keyakinan bahwa mitranya akan memberikan apa yang ia harapkan dan suatu harapan yang umumnya dimiliki seseorang bahwa kata, janji atau pernyataan orang lain dapat dipercaya. Kepercayaan juga merupakan suatu pondasi dari bisnis. Suatu transaksi bisnis antara dua pihak atau lebih akan terjadi apabila masing-masing saling mempercayai. Kotler dan Keller (2012:225), mengatakan bahwa, trust is the willingness of a frim to rely on a business partner. It depends on a number of interpersonal and interorganizational factors, such as the firm's perceived competence, integrity, honesty and benevolence. Dimana kepercayaan adalah kesediaan pihak perusahaan untuk mengandalkan mitra bisnis. Kepercayaan tergantung pada sejumlah faktor interpersonal dan antar organisasi, seperti kompetensi perusahaan, integritas, kejujuran dan kebaikan. Mowen dan Minor (2013:201) kepercayaan adalah semua pengetahuan yang dimiliki oleh konsumen dan semua kesimpulan yang dibuat konsumen tentang objek, atribut, dan manfaatnya. Morgan dan Hunt (2010:51), 
kepercayaan sebagai suatu kondisi ketika salah satu pihakyang terlibat dalam proses pertukaran yakin dengan keandalan dan integritas pihak lain. Defenisi tersebut menjelaskan bahwa kepercayaan merupakan kesediaan atau kerelaan untuk bersandar pada rekan yang terlibat dalam pertukaran yang diyakini. Ling et al (2010) indikator kepercayaan meliputi keamanan, privasi, dan keandalan. Ketiga faktor tersebut dapat dijelaskan sebagai berikut:

1. Keamanan, yaitu sejauh mana pelanggan percaya bahwa jual beli online aman bagi mereka untuk mengirimkan informasi sensitif terhadap transaksi bisnis. Keamanan berperan penting dalam mempengaruhi sikap dan minat beli karena dianggap memiliki resiko transmisi informasi seperti kartu dan lain-lain.

2. Privasi, yaitu menjaga segala prilaku konsumen selama transaksi yang kemudian berkaitan dengan kinerja toko online.

3. Keandalan, yaitu perushaan dapat mempengaruhi kepercayaan konsumen dalam penggunaan web-shopping sebagian besar konsumen menganggap bahwa perusahaan besar memiliki kemampuan yang lebih baik untuk meningkatkan kepercayaan dalam transaksi online mereka. Hal ini juga mengusulkan bahwa sebuah perusahaan dengan reputasi positif yang meningkatkan kepercayaan.

\section{HASIL DAN PEMBAHASAN}

\subsection{Hasil Penelitian}

Kuesioner tersebut didistribusikan kepada responden dengan menggunakan google document secara acak sejak Agustus s/d Oktober 2021. Berikut adalah masing-masing tabulasi responden berdasarkan karateristiknya.

\section{a. Karakteristik Responden Berdasarkan Usia}

Karakteristik responden berdasarkan usia dapat dilihat pada tabel 1 dibawah ini:

Tabel 1. Usia Responden

\begin{tabular}{ccc}
\hline Usia (Tahun) & Frekuensi & Persentasi $(\%)$ \\
\hline$\leq 23$ & 28 & $27.1 \%$ \\
$24-28$ & 30 & $29.1 \%$ \\
$29-33$ & 26 & $25.2 \%$ \\
$34-38$ & 19 & $18.6 \%$ \\
Total & 103 & $100 \%$ \\
\hline
\end{tabular}

Responden berdasarkan kategori usia yaitu dengan usia $\leq 23$ tahun adalah sebanyak 28 (27.1\%), usia 24-48 tahun sebanyak 30 (29.1\%), usia 29 - 33 tahun sebanyak 26 (25.2\%), dan usia 34-38 tahun sebanyak 19 (18.6\%). Dengan demikian, dapat disimpulkan bahwa, responden dengan rentang usia 18-33 tahun adalah mendominasi kategori responden berdasarkan usia. Artinya, nasabah pegadaian berdasarkan penelitian ini menggunakan jasa PT Pegadaian didominasi oleh usia muda dengan rentang 18-33 tahun.

\section{b. Karakteristik Responden Berdasarkan Jenis Kelamin}

Kategori responden berdasarkan jenis kelamin dapat dilihat pada tabel 2 dibawah ini:

Tabel 2. Jenis Kelamin

\begin{tabular}{lcc}
\hline Gender & Frekuensi & Persentasi (\%) \\
\hline Pria & 45 & $43.6 \%$ \\
Wanita & 58 & $56.4 \%$ \\
Total & 103 & $100 \%$ \\
\hline
\end{tabular}

Berdasarkan data yang telah diperoleh jenis kelamin pria sebanyak 45 (43.6\%) dan wanita sebanyak 58 (56.4\%). Berdasarkan data tersebut, dapat disimpulkan bahwa responden dengan jenis kelamin wanita adalah yang lebih banyak dibandingkan dengan responden berjenis kelamin pria.

\section{c. Karakteristik Responden Berdasarkan Tingkat Pendidikan}

Karakteristik responden berdasarkan tingkat Pendidikan dapat dilihat pada tabel 3 dibawah ini:

Tabel 3. Tingkat Pendidikan

\begin{tabular}{ccc}
\hline Pendidikan Terakhir & Frekuensi & Persentasi (\%) \\
\hline SLTA & 18 & $27.1 \%$ \\
D-III & 11 & $10.6 \%$ \\
Sarjana & 51 & $49.5 \%$ \\
Lainnya & 13 & $12.8 \%$ \\
Keseluruhan & 103 & $100 \%$ \\
\hline
\end{tabular}

Untuk jumlah responden berdasarkan tingkat Pendidikan SLTA/Sederajat adalah sebanyak 28 (27.1\%), D-III sebanyak 11 (10.6\%), Sarjana sebanyak 51 (49.5\%) dan lainnya sebanyak 13 (12.8\%). Sehingga, untuk karakteristik 
responden berdasarkan tingkat Pendidikan dapat disimpulkan bahwa didominasi dengan responden yang memiliki Pendidikan sarjana (S-1).

d. Karakteristik Responden Berdasarkan Penggunaan Layanan Pegadaian

Karakteristik responden berdasarkan penggunaan layanan pegadaian dapat dilihat pada tabel 4 dibawah ini:

Tabel 4. Penggunaan Layanan Pegadaian

\begin{tabular}{lcc}
\hline Lama Bertransaksi (bln) & Jumlah & Persentasi (\%) \\
\hline$\leq 6$ & 29 & $28.1 \%$ \\
$6-12$ & 18 & $17.4 \%$ \\
$\geq 12$ & 56 & $54.5 \%$ \\
Total & 103 & $100 \%$ \\
\hline
\end{tabular}

Untuk kategori ini akan berfokus kepada lama waktu penggunaan aplikasi pegadaian (online) oleh responden. Responden dapat dikategorikan berdasarkan waktu/lama bertransaksi lebih atau sama dengan enam bulan adalah sebanyak $29(28.1 \%)$, enam hingga dua belas bulan sebanyak 18 (17.4\%), dan lebih atau sama dengan dua belas bulan sebanyak $56(54.5 \%)$. Sehingga, responden penelitian ini adalah didominasi oleh mereka yang telah bertransaksi lebih atau sama dengan dua belas bulan.

\section{e. Karakteristik Responden Berdasarkan Jenis Layanan Yang Digunakan}

Karakteristik responden berdasarkan jenis layanan yang dapat dilihat pada tabel 5. dibawah ini:

Tabel 5. Jenis Layanan Pegadaian

\begin{tabular}{lll}
\hline Jenis Layanan & Frekuensi & Persentasi $(\%)$ \\
\hline Layanan Offline & 61 & $59.2 \%$ \\
Layanan Online & 42 & $40.8 \%$ \\
Total & 103 & $100 \%$ \\
\hline
\end{tabular}

Fokus kepada jenis layanan yang digunakan dikategorikan menjadi dua yaitu layanan online dan offline. Adapun responden yang menggunakan layanan offline adalah sebanyak 61 (59.2\%) dan yang menggunakan layanan online adalah sebanyak $42(40.8 \%)$. Sehingga, dapat disimpulkan bahwa responden dipenelitian ini didominasi oleh nasabah yang menggunakan layanan offline dalam bertransaksi di PT Pegadaian.

\section{Analisis Data}

Tahapan analisis dimulai dari analisis model pengukuran (measurement model) yang digunakan untuk menganalisis sebuah konstruk terhadap indikator (measures) variabel. Pendekatan yang digunakan untuk metode model pengukuran adalah convergent dan discriminant validity. Convergent validity dievaluasi dengan membandingkan nilai average variance extracted $\mathrm{AVE}>0.50$; factor loadings/CFA > 0.60; dan composite reliability $\mathrm{CR}>0.70$. Berikut tabel analisis convergent validity.

Tabel 6. Analisis Convergent Validity

\begin{tabular}{|c|c|c|c|c|c|}
\hline Variabel & Item Kuesioner & Code & CFA & $\mathrm{CR}$ & AVE \\
\hline \multirow{7}{*}{$\begin{array}{l}\text { Konfigurasi } \\
\text { Saluran } \\
\text { Layanan }\end{array}$} & $\begin{array}{l}\text { Saya mengetahui keberadaan semua saluran layanan yang } \\
\text { disediakan PT Pegadaian. }\end{array}$ & TSL1* & 0.539 & 0.837 & 0.508 \\
\hline & $\begin{array}{l}\text { Saya mengetahui perbedaan antara atribut layanan diseluruh } \\
\text { saluran yang berbeda yang dimiliki oleh PT Pegadaian. }\end{array}$ & TSL2* & 0.664 & & \\
\hline & Saya mengetahui bagaimana memanfaatkan saluran yang & TSL* & 0.681 & & \\
\hline & $\begin{array}{l}\text { berbeda untuk memenuhi kebutuhan saya akan produk PT } \\
\text { Pegadaian }\end{array}$ & & & & \\
\hline & $\begin{array}{l}\text { Saya dapat memilih saluran alternatif untuk layanan tertentu } \\
\text { yang ditawarkan oleh produk PT Pegadaian }\end{array}$ & LPS $1 *$ & 0.724 & & \\
\hline & $\begin{array}{l}\text { Saya dapat menyelesaikan tugas pilihan melalui saluran } \\
\text { individu yang disediakan oleh produk PT Pegadaian. }\end{array}$ & LPS2* & 0.773 & & \\
\hline & $\begin{array}{l}\text { Apapun saluran yang saya pilih, saya dapat menggunakan } \\
\text { saluran lain untuk mendapatkan informasi atau bantuan } \\
\text { mengenai produk PT Pegadaian }\end{array}$ & LPS3* & 0.717 & & \\
\hline \multirow{5}{*}{$\begin{array}{l}\text { Interaksi } \\
\text { Terintegrasi }\end{array}$} & $\begin{array}{l}\text { Menurut perasaan saya layanan yang diberikan oleh PT } \\
\text { Pegadaian konsisten diberbagai saluran }\end{array}$ & $\mathrm{KP} 1 *$ & 0.616 & 0.777 & 0.635 \\
\hline & Menurut saya, gambaran layanan yang diberikan oleh PT & $\mathrm{KP} 2 *$ & 0.824 & & \\
\hline & Pegadaian konsisten diberbagai saluran & & & & \\
\hline & $\begin{array}{l}\text { Menurut saya, kinerja layanan yang diberikan oleh PT } \\
\text { Pegadaian konsisten diberbagai saluran }\end{array}$ & $\mathrm{KP} *$ & 0.769 & & \\
\hline & Saya berniat untuk terus membeli produk PT Pegadaian & $\mathrm{MBK} 1 *$ & 0.835 & 0.846 & 0.524 \\
\hline
\end{tabular}




\begin{tabular}{|c|c|c|c|c|c|}
\hline Variabel & Item Kuesioner & Code & CFA & $\mathrm{CR}$ & AVE \\
\hline niat & $\begin{array}{l}\text { Saya bermaksud untuk terus memperoleh produk dan } \\
\text { layanan dari produk PT Pegadaian }\end{array}$ & $\mathrm{MBK} 2 *$ & 0.754 & \multirow{7}{*}{0.843} & \multirow{7}{*}{0.643} \\
\hline $\begin{array}{l}\text { pembelian } \\
\text { kembali }\end{array}$ & $\begin{array}{l}\text { Saya bermaksud memilih produk PT Pegadaian sebagai } \\
\text { produk pilihan untuk pembelian saya di masa } \\
\text { mendatang }\end{array}$ & MBK3* & 0.813 & & \\
\hline \multirow{5}{*}{ Kepercayaan } & $\begin{array}{l}\text { Saya percaya bahwa aplikasi Pegadaian Digital Service } \\
\text { merupakan platform yang aman dalam membeli produk PT } \\
\text { Pegadaian }\end{array}$ & $\mathrm{K} 1 *$ & 0.729 & & \\
\hline & $\begin{array}{l}\text { Saya percaya bahwa Aplikasi Pegadaian Digital Service } \\
\text { yang saya kunjungi dapat diandalkan untuk mendapatkan }\end{array}$ & $\mathrm{K} 2 *$ & 0.691 & & \\
\hline & $\begin{array}{l}\text { Aplikasi Pegadaian Digital Service lebih memudahkan } \\
\text { nasabah dalam menyediakan produk yang menguntungkan } \\
\text { untuk masa yang akan datang dibandingkan dnegan cara } \\
\text { offline melalui kantor cabang Pegadaian }\end{array}$ & $\mathrm{K} 3 *$ & 0692 & & \\
\hline & $\begin{array}{l}\text { PT Pegadaian selalu menjamin keamanan dari privasi } \\
\text { nasabah }\end{array}$ & $\mathrm{K} 4 *$ & 0.768 & & \\
\hline & $\begin{array}{l}\text { Saya percaya pihak PT Pegadaian selalu mengutamakan } \\
\text { keterusterangan dalam memberikan pelayanan kepada } \\
\text { nasabah Pegadaian }\end{array}$ & $\mathrm{K} 5 *$ & 0.736 & & \\
\hline
\end{tabular}

Keterangan: Item TSL.1* Dieliminasi/Dihapus Berdasarkan Ketentuan Nilai Fact Loadings/CFA 0.60; KP.1* Dieliminasi Dengan Tujuan Meningkatkan Nilai AVE.

Berdasarkan analisis convergent validity yang dilakukan, diperoleh beberapa kesimpulan terkait hubungan setiap indikator pengukuran variabel dengan kontruk penelitian. Untuk konstruk konfigurasi saluran layanan (X1) awalnya memiliki item pengukuran sebanyak 6 item, akan tetapi terdapat 1 (satu) item pengukuran yang tidak memenuhi yaitu, "Saya mengetahui keberadaan semua saluran layanan yang disediakan PT Pegadaian" (TSL.1*) karena nilai CFA < 0.60; sehingga dieliminasi atau dihapus. Penghapusan item pengukuran yang tidak memenuhi dilakukan dengan tujuan untuk memperoleh atau meningkatkan nilai AVE seperti pada item pengukuran (KP.1*), sehingga, setiap item yang memiliki nilai dibawah < 0,60 maka akan dihapus. Selanjutnya, dilakukan analisis kembali untuk memperoleh nilai yang telah ditentukan. Setelah dilakukan analisis lebih lanjut, maka diperoleh seluruh nilai factor loadings telah memenuhi kriteria CFA > 0.60; CR > 0.70 dan AVE > 0.50. Berdasarkan hasil yang diperoleh, maka dapat disimpulkan secara convergent validity data telah memenuhi dan dapat digunakan untuk analisis model structural.

\section{Analisis Discriminant Validity}

Discriminant validity dilaksanakan dengan menggunakan metode fornell-larcker criterion; dimana, nilai akar pangkat dua dari average variance extracted (AVE) dibandingkan dengan interkorelasi masing-masing variabel penelitian yang diperoleh. Berikut ini hasil analisis discriminant validity yang diperoleh:

Tabel 7. Analisis Discriminant Validity (Fornell-Larcker Criterion)

\begin{tabular}{lllll}
\hline & KSL & IT & KP & MPK \\
\hline KSL & 0,713 & & & \\
IT & 0,626 & 0,797 & & \\
KP & 0,593 & 0,681 & 0,724 & \\
MPK & 0,641 & 0,605 & 0,764 & 0,802 \\
\hline
\end{tabular}

Keterangan: Nilai diagonal dan bercetak tebal adalah akar pangkat dua dari AVE; sementara nilai lainnya adalah interkorelasi masing - masing variabel.

Berdasarkan nilai yang diperoleh pada tabel 7, disimpulkan bahwa nilai dari akar pangkat dua dari masingmasing variabel adalah lebih besar dibandingkan dengan nilai korelasi interkorelasi masing-masing variabel. Sehingga, discriminant validity yang dilaksanakan sebagai indicator model pengukuran telah memenuhi dan dapat dilaksanakan ke tahap analisis struktural.

\section{Analisis Model Struktural}

Model structural menggunakan dua metode secara umum, yaitu, dengan nilai model fit indeks (goodness of fit index) dan nilai $\mathrm{R}^{2}$. Berikut adalah hasil analisis model structural melalui Smart-PLS 3.0 dapat dilihat pada tabel 8. dan gambar 2. Pertama, hasil analisis model fit indeks dalam penelitian ini dilakukan dengan membandingkan nilai SRMR = 0.095 dengan ketentuan nilai 0.08 - 0.10 (memenuhi), nilai chi-square 251.240 (moderate) mendekati " 0 ", dan nilai $\mathrm{NFI}=0.621$ (moderate) dengan ketentuan nilai $0-1$. Dapat disimpulkan bahwa melalui kriteria model fit indeks bahwa data yang digunakan adalah telah memenuhi kriteria model fit (goodness of fit index) untuk model structural. 
Tabel 8. Analisis Model Fit Indeks

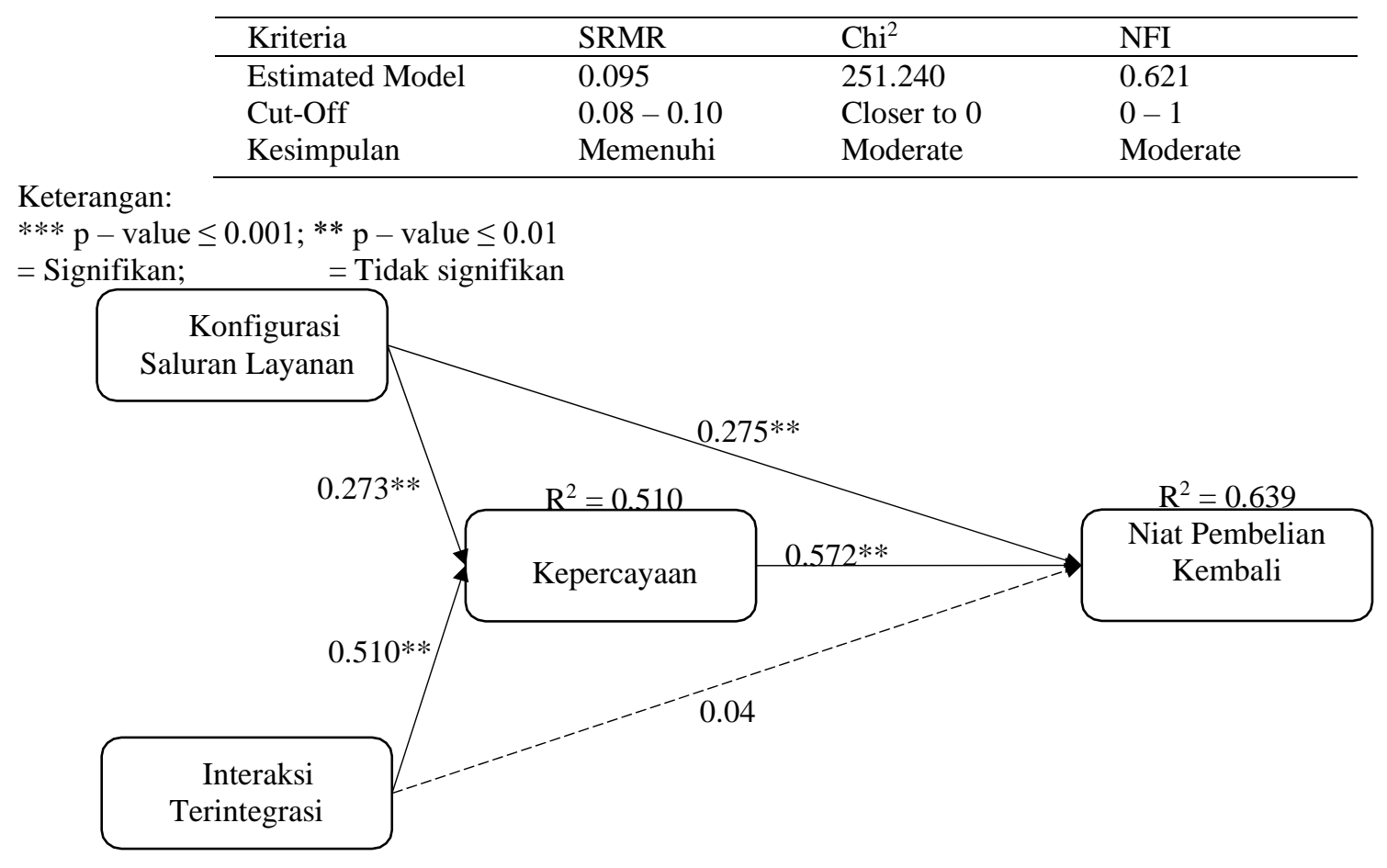

Gambar 2. Analisis Model Struktural

Berdasarkan hasil analisis yang dilakukan, maka diperoleh nilai $\mathrm{R}^{2}$ sebesar $0.510(51 \%)$ dan $0.639(63.9 \%)$ lebih besar dari nilai 0.10 sebagai syarat yang digunakan. Sehingga, dapat disimpulkan bahwa model secara keseluruhan memiliki pengaruh variance dari variabel exogeneous yang tinggi dan dapat digunakan untuk menganalisis variabel endogen.

\section{Pengujian Hipotesis}

Pengujian hipotesis terdiri dari dua jenis yaitu pengujian hipotesis secara direct effect dan indirect effect (mediating). Kriteria yang digunakan untuk menguji hipotesis adalah nilai T-value 1.96 dibandingkan dengan nilai yang diperoleh berdasarkan hasil analisis. Sementara itu, nilai signifikansi p-value 0.05 dibandingkan dengan nilai yang diperoleh dari hasil analisis untuk mengetahui seberapa signifikan pengaruh yang diberikan variabel independent terhadap dependent. Berikut adalah hasil pengujian hipotesis direct effect seperti yang ditunjukkan pada tabel 9 dan pengujian hipotesis indirect effect (mediating) ditunjukkan pada tabel 10 dibawah ini:

Tabel 9. Pengujian Hipotesis (Direct Effect)

\begin{tabular}{|c|c|c|c|c|}
\hline Hubungan Variabel & $\begin{array}{l}\text { Koefisien } \\
\text { Jalur }\end{array}$ & Kesimpulan & T-Value & P-Value \\
\hline $\begin{array}{llll}\text { Konfigurasi } & \text { Saluran } & \text { Layanan } & \rightarrow \\
\text { Kepercayaan } & & \end{array}$ & 0.273 & 2.793 & 0.005 & H.1a (Diterima) \\
\hline Interaksi Terintegrasi $\rightarrow$ Kepercayaan & 0.510 & 5.895 & 0.000 & H.1b (Diterima) \\
\hline Kepercayaan $\rightarrow$ Minat Pembelian Kembali & 0.572 & 5.134 & 0.000 & H.2 (Diterima) \\
\hline $\begin{array}{l}\text { Konfigurasi Saluran Layanan } \rightarrow \text { Minat } \\
\text { PembelianKembali }\end{array}$ & 0.275 & 2.857 & 0.004 & H.3a (Diterima) \\
\hline $\begin{array}{l}\text { Interaksi Terintegrasi } \rightarrow \text { Minat Pembelian } \\
\text { Kembali }\end{array}$ & 0.043 & 0.364 & 0.715 & H.3b (Ditolak) \\
\hline $\begin{array}{l}\text { Keterangan: T-Value > } 1.96 \text { (Hipotesis } \\
\text { Diterima); } T \text {-Value } \\
\text { (Signifikan); } P \text {-Value }>0,05 \text { (Tidak Signifikan) }\end{array}$ & $<1.96$ & (Hipotesis & Ditolak & P-Value $<0.05$ \\
\hline
\end{tabular}

Tabel 10. Pengujian Hipotesis (Mediating Effect)

\begin{tabular}{lllll}
\hline Parameter & Koefisien Jalur & T-Value & P-Value & Kesimpulan \\
\hline $\begin{array}{l}\text { Konfigurasi Saluran Layanan } \rightarrow \text { Kepercayaan } \\
\rightarrow \text { Minat } \rightarrow \text { niat pembelian kembali }\end{array}$ & 0.157 & 2.208 & 0.028 & $\begin{array}{l}\text { H.4a } \\
\text { (Diterima) }\end{array}$ \\
$\begin{array}{l}\text { Interaksi Terintegrasi } \rightarrow \text { Kepercayaan } \rightarrow \text { Minat } \\
\text { Pembelian }\end{array}$ & 0.292 & 4.316 & 0.000 & $\begin{array}{l}\text { H.4b } \\
\text { (Diterima) }\end{array}$ \\
\hline
\end{tabular}


Keterangan: T-Value > 1.96 (Mediating); T-Value $<1.96$ (Non-mediating); P-Value $<0.05$ (Significant); P-Value > 0,05 (Insignificant)

\subsection{Pembahasan}

\section{a. Omnichannel Integration Quality terhadap Kepercayaan Konsumen}

Penelitian ini menunjukkan bahwa variabel konfigurasi saluran layanan berpengaruh secara signifikan terhadap kepercayaan, yang artinya hipotesis diterima. Penelitian ini didukung oleh penelitian Hanh Le dan Nguyen- Le (2021), yang menunjukkan bahwa variabel konfigurasi saluran layanan berpengaruh signifikan terhadap kepercayaan. Konfigurasi saluran layanan mengacu pada kombinasi yang tersedia dari komponen layanan dan saluran pengiriman yang terkait Saluran layanan mengacu pada sejauh mana pelanggan dapat memilih saluran alternatif untuk layanan tertentu atau dapat menyelesaikan tugas yang disukai melalui saluran individu. Konfigurasi saluran layanan berpengaruh terhadap kepercayaan, karena dengan adanya transparansi konfigurasi saluran layanan mengacu pada sejauhmana pelanggan mengetahui keberadan saluran dan layanan yang tersedia serta perbedaan antara atribut layanan tersebut dalam lintas saluran. Penelitian ini telah membuktikan bahwa konfigurasi saluran layanan yang terdapat di PT Pegadaian (Persero) Medan dapat berpengaruh signifikan terhadap kepercayaan pelanggan.

Variabel interaksi terintegrasi berpengaruh secara signifikan terhadap kepercayaan, yang artinya hipotesis diterima. Penelitian ini didukung oleh penelitian Hanh Le dan Nguyen-Le (2021) yang menunjukkan bahwa variabel interaksi terintegrasi berpengaruh signifikan terhadap kepercayaan. Interaksi terintegrasi berarti bahwa saluran layanan saling terikat satu sama lain. PT Pegadaian (Persero) Medan yang telah menerapkan interaksi teringtegrasi agar selalu memastikan saluran terintegrasi yang sinergis untuk menghilangkan gesekan selama perjalanan pelanggan, yang bertujuan meningkatkan kepercayaan pelanggan.Penelitian ini membuktikan bahwa dengan interaksi terintergrasi yang terdapat di PT Pegadaian (Persero) Medan dapat berpengaruh signifikan terhadap kepercayaan pelanggan.

\section{b. Kepercayaan Terhadap Minat Pembelian Kembali}

Hasil analisis menunjukkan bahwa variabel kepercayaan berpengaruh secara signifikan terhadap minta beli kembali yang artinya hipotesis diterima. Penelitian ini didukung penelitian Ikranegara (2017), Rosdiana (2019) dan Tanjung (2019) yang menunjukkan bahwa variabel kepercayaan berpengaruh signifikan terhadap minat pembelian kembali. Kepercayaan konsumen merupakan pengetahuan konsumen mengenai suatu objek, atributnya, dan manfaatnya. Kepercayaan menjadi faktor kunci dalam setiap transaksi jual beli secara baik secara offline maupun online. Sedangkan minat beli konsumen merupakan sebuah perilaku konsumen dimana konsumen mempunyai keinginan dalam memilih, menggunakan, dan mengkonsumsi atau bahkan menginginkan suatu produk yang ditawarkan. Dengan adanya kepercayaan maka konsumen akan melakukan pembelian pertama ataupun pembelian kembali, karena merasa yakin terhadap produk yang ditawarkan. Penelitian ini membuktikan bahwa dengan adanya kepercayaan nasabah PT Pegadaian (Persero) Medan dapat berpengaruh signifikan terhadap minat pembelian Kembali.

\section{c. Omnichannel Integration Quality Terhadap Minat Pembelian Kembali}

Hasil analisis menunjukkan bahwa variabel konfigurasi saluran layanan berpengaruh secara signifikan terhadap niat pembelian kembali, yang artinya hipotesis diterima. Penelitian ini didukung oleh penelitian Lee, et al (2018) dan Prabowo (2019), yang menunjukkan bahwa variabel konfigurasi saluran layanan berpengaruh signifikan terhadap kepercayaan Tujuan omnichannel adalah untuk mengikuti perkembangan teknologi, mempermudah, mempersingkat waktu dan menimbulkan rasa keingintahuan serta minat beli konsumen pada produk-produk yang ditawarkan.

Perkembangan konfigurasi saluran layanan yang ditawarkan melalui digital service akan berpengaruh terhadap niat pembelian kembali konsumen. Hasil penelitian ini menunjukkan variabel konfigurasi saluran layanan berpengaruh signifikan terhadap niat pembelian kembali di PT Pegadaian (Persero) Medan. Sedangkan niat pembelian kembali yang artinya hipotesis ditolak. Penelitian ini berbeda dengan penelitian Sugasti dan Kusniawati (2019) yang menunjukkan variabel interaksi terintegrasi berpengaruh signifikan terhadap kepercayaan. Hasil penelitian ini membuktikan bahwa interaksi terintergrasi yang terdapat di PT Pegadaian (Persero) Medan tidak berpengaruh signifikan terhadap kepercayaan pelanggan.

\section{d. Mediating Effect Kepercayaan Dalam Hubungan Omnichannel Integration Quality Terhadap Niat Pembelian Kembali}

Peranan mediasi niat pembelian kembali berpengaruh signifikan. Hal ini menunjukkan bahwa kepercayaan dalam penelitian ini menjadi faktor kunci keberhasilan dalam hubungan antara saluran konfigurasi saluran layanan terhadap niat pembelian kembali. Konfigurasi saluran layanan terdiri dari komponen dan saluran pengirim yang terkait sejauhmana pelanggan dapat memiliih saluran alternatif untuk layanan tertentu untuk menyelesaikan pembelian di PT Pegadaian. Dalam hal ini kepercayaan yang memberikan pengaruh yang signifikan, baik saluran online maupun offline yang disediakan oleh PT Pegadaian dapat mengeksekusi pembelian kembali melalui kepercayaan. Kepercayaan konsumen merupakan sebagai faktor kunci untuk konsumen dapat memiliki sikap dan melakukan pembelian. Sehingga, dapat dikatakan bahwa kepercayaan yang signifikan dapat memediasi konfigurasi saluran layanan terhadap minat pembelian kembali.

Variabel interaksi terintegrasi secara langsung memiliki pengaruh tidak signifikan terhadap niat pembelian kembali. Interaksi terintegrasi adalah kondisi dimana perusahaan menyediakan layanan kepada konsumen melalui interaksi setiap saluran yang digunakan oleh konsumen dalam bertransaksi dengan PT Pegadaian. 


\section{KESIMPULAN}

Kesimpulan yang dihasilkan dalam penelitian ini adalah Omnichannel integration quality (konfigurasi saluran layanan dan interaksi terintegrasi) berpengaruh signifikan terhadap kepercayaan dan menunjukkan bahwa hipotesis 1a dan $1 \mathrm{~b}$ adalah diterima. Kepercayaan berpengaruh signifikan terhadap niat pembelian kembali dan menunjukkan bahwa hipotesis 2 adalah diterima. Omnichannel integration quality (konfigurasi saluran layanan dan interaksi terintegrasi) berpengaruh signifikan terhadap niat pembelian kembali kembali dan menunjukkan bahwa hipotesis $3 \mathrm{a}$ dan $3 \mathrm{~b}$ adalah diterima. Omnichannel integration quality (konfigurasi saluran layanan dan interaksi terintegrasi) berpengaruh terhadap niat pembelian kembali melalui variabel mediasi kepercayaan dan menunjukan bahwa hipotesis 4a adalah diterima, sedangkan hipotesis $4 \mathrm{~b}$ ditolak. Kepercayaan mampu memediasi variabel Omnichannel integration quality (konfigurasi saluran layanan dan interaksi terintegrasi) berpengaruh terhadap niat pembelian kembali. Berikut saran dan rekomendasi yang dapat dipedomani bahwa interaksi terintegrasi tidak memiliki pengaruh yang signifikan terhadap niat pembelian kembali, namun interaksi terintegrasi yang sinergis memiliki pengaruh yang signifikan terhadap peningkatan kepercayaan pelanggan. Untuk itu, perlu dilakukan sosialisasi kepada seluruh lapisan masyarakat tentang penggunakan aplikasi Pegadaian Digital Service guna mempermudah, mempersingkat waktu dan menimbulkan rasa niat keingintauan serta minat beli masyarakat terhadap produk yang ditawarkan, sehingga pelanggan terutama kalangan anak muda lebih tertarik untuk memahami skema menabung emas dan produk pegadaian lainnya. Pengoptimalan pelayanan kepada nasabah dapat menimbulkan kesan baik atau feedback yang positif terhadap perusahaan yang mampu menimbulkan kepercayaan lebih terhadap perusahaan dan meningkatkan niat pembelian kembali. Ketika konsumen sudah merasa nyaman dan aman akan suatu produk, maka konsumen tersebut percaya terhadap perusahaan dan bertahan serta konsisten akan produk. Untuk penelitian selanjutnya, menggali lebih dalam mengenai omnichannel quality dalam industri perbankan, industri fashion dan menggunakan sampel dari generasi millennial Dimana generasi millennial merupakan generasi yang sangat rentan terhadap kepercayaan dan lebih banyak menggunakan waktunya untuk berselancar di dunia internet.

\section{REFERENCES}

Adi, Bangun Wibowo, 2015. Pengaruh Suasana Toko, Promosi, dan Lokasi Terhadap Minat Beli di Planet Distro Kota Banjarmasin. Skripsi. Fakultas Ekonomi Universitas Negeri Yogyakarta.

Ali Hasan. (2018). Jurnal Indovisi; Pengaruh Citra Merek, Kualitas Produk dan harga Terhadap Minat Beli Pakaian. Indonesoan Indovisi Institute, 1(Iii), 83-104. Diambil dari http://journal.dosenindonesia.org

Bitner, Mary Jo. 2002, "Evaluating Service Encounters : The Effects Of Physical Surrounding And Employee Responses,” Journal Of Marketing, April, P. $69-82$

Bianchi, R., Cermak, M., \& Dusek, O. (2016). More than digital plus traditional: A truly omnichannel customer experience. Retrieved from http://www.mckinsey.com/businessfunctions/operations/our-insights/more-than-digital-plus-traditional-atrulyomnichannelcustomer

BusinessWire. (2016). ICSC survey: In-store to beat out online over thanksgiving shopping weekend. Retrieved from http://sports.yahoo.com/news/icsc-survey-store-beat-online140000813.html

Cox, Roger and Paul Brittan. 2016), Retailing an Introduction. Fifth Edition: Pearson Education Limited. London.

Gilles, S. (2015). The 5 biggest challenges facing omnichannel retailers in 2015 . Retrieved from http://www.applianceretailer.com.au/2015/03/oped-the-5-biggest-challenges-

facing-omnichannel-retailers-in2015/\#.WFA32XecZSw.

Hanh Le dan Nguyen- Le (2021), A moderated mediatingmechanism of omnichannelcustomer experiences. International Journal of Retail \&Distribution Management. DOI10.1108/IJRDM-02-2020-0054

Ikranegara (2017), Pengaruh Belanja, Kepercayaan Online, dan Pengalaman Pembelia Terhadap Minat Beli Secara Online (Studi Kasus Pada Toko Online Bukalapak). Skripsi. Diakses pada Juli 2021.

Jinzhe Yan, Kyuseop Kwak. 2016. Empirical Study on Omni-Channel Effect: Eviden form Departement Store Tersedia:http://www.ejmt.org/download/201611/6.JMT\%25EC\%2597\%2584\%25EA\%25B8\% 2588\%25EC\%25B2\%25A0.pdf.

Kotler, P. \& Keller, K.L. (2012), Manajemen Pemasaran Jilid I Edisi ke 12. Jakarta: Erlangga

Laela, Nina, Kusniawati dan Prabowo. (2019). "Pengaruh Omni-Channel Marketing Terhadap Minat Beli Konsumen (Suatu Studi Pada Produk Tabungan Emas PT Pegadaian (Persero) Syariah Cabang Padayungan)". Skripsi. Fakultas Ekonomi. Manajemen. Universitas Galuh

Lee, Z.W.Y., Chan, T.K.H., Chong, A.Y.L. and Thadani, D.R. (2019), "Customer engagement through omnichannel retailing: the effects of channel integration quality", Industrial Marketing Management, Vol. 77, pp. 90-101.

Lexmark (2016). Customer engagement for trailblazers. Retrieved from http://www. kofax.com/ /media/Files/Kofax/Go/customerengagement-for-trailblazers-en.pdf.

Ling, K. C., Chai, L. T., \& Piew, T. Hoi. (2010). The effects of shopping orientation, online trust and prior online purchase experience toward customers' online purchase intention. International Business Research, 3(3).

Matt, B, (2016). Bring communities into your customer engagement management. strategy. Retrieved from https://mindtouch.com/resources/bringing-communities- into-your-customer-engagement-management-strategy 4 June 2015 .

Mowen, John C dan Minor, Micheal. (2012). Perilaku Konsumen dialih bahasakan oleh Dwi Kartika Yahya. Jakarta : Erlangga.

Mowen, John. C dan Minor, Michael. (2010), Perilaku Konsumen. Edisi Kelima. Jilid 1. Edisi Bahasa Indonesia. Terjemahan oleh Lina Salim. 2002. Jakarta: PT Penerbit Erlangga.

Neslin, S. A., and Gedenk, K. (2006). Pursuing the valueconscious consumer: Store brands versus national brand promotions. Journal of Marketing, 65(January), 71-89. 
Payne, A., \& Frow, P. (2004). The role of multichannel integration in customer relationship management. Industrial Marketing Management, 33(6), 527-538.

Rosdiana, R., Haris, I. A., \& Suwena, K. R. (2019). Pengaruh Kepercayaan Konsumen terhadap Minat Beli Produk Pakaian Secara Online. Jurnal Pendidikan Ekonomi Undiksha, 11(1).

Seck, A. M., \& Philippe, J. (2013). Service encounter in multi-channel distribution con- text: Virtual and face-to-face interactions and consumer satisfaction. The Service Industries Journal, 33(6), 565-579.

Sinulingga, Sukaria. 2014. Metode Penelitian. Medan: USU Press

Sousa, R. and Voss, C.A. (2006), "Service quality in multichannel services employing virtual channels", Journal of Service Research, Vol. 8 No. 4, pp. 356-3711

Tanjung, Jenifer Katherine. (2019). "Peran Mediasi Kepercayaan Pada Pengaruh Kualitas Website, Perceived Benefits, E-Wom, Keamanan Terhadap Minat Beli Ulang Secara Online (Studi Pada Konsumen Lazada di Yogyakarta)". Skripsi. Fakultas Ekonomi. Manajemen. Universitas Sanata Dharma Yogyakarta.

Tjiptono, Fandy. (2015), Strategi Pemasaran. Edisi Pertama. Andi Ofset.Yogyakarta. 